\title{
UPAYA HUKUM PRAPERADILAN DALAM SISTEM PERADILAN PIDANA DI INDONESIA
}

\author{
I Made Wisnu Wijaya Kusuma, I Made Sepud, Ni Made Sukaryati Karma \\ Fakultas Hukum Universitas Warmadewa, Denpasar-Bali, Indonesia \\ imadewisnu69@gmail.com sepudmade@gmail.com Sukariati64@gmail.com
}

\begin{abstract}
Abstrak
Sistem peradilan pidana, hukum acara pidana Indonesia menganut asas praduga tak bersalah. Maka, seseorang haruslah dilindungi hak asasinya. KUHAP membentuk lembaga baru yaitu praperadilan. Berdasarkan penelitian ini penulis mengangkat rumusan masalah : 1. Bagaimanakah pengaturan praperadilan dalam sistem peradilan pidana di Indonesia, 2. Bagaimanakah keabsahan dari praperadilan yang belum di putus apabila materi pokok perkara telah di sidangkan. Metode penelitian yang digunakan adalah normatif. Metode pendekatan yang digunakan pendekatan perundang- undangan, pendekatan analisis konsep hukum. Kewenangan praperadilan sesuai dengan Pasal 77 KUHAP adalah memeriksa sah atau tidaknya upaya paksa yaitu penangkapan dan penahanan serta memeriksa sah atau tidaknya penghentian penyidikan atau penghentian penuntutan, ganti kerugian dan rehabilitasi. Hakim Sarpin menyatakan bahwa, Sprindik yang menjadi dasar penyidikan Budi Gunawan tidak sah. Pengaturan praperadilan di atur dalam UU No 8 tahun 1981 mengenai hukum acara pidana pada pasal 77 KUHAP yaitu pra peradilan merupakan wewenang pengadilan negeri untuk memeriksa dan memutus, Mahkamah Konstitusi Nomor 21/PUU- XII/2014, kewenangan lembaga praperadilan juga termasuk sah atau tidaknya penetapan tersangka, penggeledahan dan penyitaan. keabsahan penyidikan yang dilakukan KPK terkait penetapan tersangka Budi Gunawan tidak sah karenanya penetapan tidak memiliki kekuatan hukum mengikat. Maka materi pokok perkara praperadilan yang disidangkan dinyatakan gugur.
\end{abstract}

Kata Kunci: Upaya hukum; Praperadilan; Sistem peradilan pidana

\begin{abstract}
Criminal justice system and Indonesian criminal procedural law adhere to presumption of innocence. Thus, a person must protect his human rights. KUHAP formed a new institution, namely pretrial. Based on this research authors raise formulation problems: 1. How pretrial regulation criminal justice system Indonesia, 2. How validity pretrial that has not been decided if the subject matter case has been tried. Type research used normative. The approach used is statutory approach, shortening analysis legal concepts. pre-trial authority according to Article 77 Criminal Procedure Code examines whether or not coercive measures are arrest and detention well examine whether or not termination investigation or prosecution, compensation and rehabilitation legal or not. Judge Sarpin stated that Sprindik, which became the basis for Budi Gunawan's investigation, was invalid. pretrial regulations are regulated Law No. 8 of 1981 on Criminal Procedure Law in article 77 Criminal Procedure Code, namely pretrial, which authority district court examine and decide, Constitutional Court Number 21/PUU -XII/2014, authority pre-trial institution also includes whether or not determination suspects valid, searches and confiscation. Validity investigations carried out by KPK regarding determination suspect Budi Gunawan was invalid therefore determination had no binding legal force. The Subject matter pretrial case being tried declared null and void.
\end{abstract}

Keywords: Legal Efforts; Pre-trial; Criminal justice system

\section{PENDAHULUAN}

UUD 1945 mengartikan pasti maka. negara indonesia berlandaskan pada hukum, bukan beralaskan pada kuasa belaka. bermakna bahwa negara RI bersifat demokratis mengusung HAM dengan mengamankan penduduk negara beriringan kedudukan hukum, pemerintahan, serta wajib mematuhi hukum serta pemerintahan tidak terkecuali (Kansil, 1989). 
Meningkat paham hukum lahir UU No. 8 tahun 1981 mengenai hukum acara pidana, sasaran hendak dicapai KUHAP ialah memberikan pengamanan akan harga diri tersangka. KUHAP melindungi HAM utama tersangka maupun terdakwa dalam mekanisme peradilan pidana Indonesia (Atmasasmita, 1983). Peristiwa diduga yakni perbuatan pidana, petugas pihak berwajib melaksanakan pemeriksaan, penuntutan untuk mengadili kejadian. Dalam menggelar tugas, hukum acara pidana menyerahkan kewenangan tentang mereka untuk mengerjakan tindakan sesuai dengan hak asasi terdakwa sebagai manusia sebagaimana tertulis dalam UUD 1945 (Alfifah, 1986).

Dalam hukum acara pidana Indonesia mengistilahkan asas praduga tak bersalah. Oleh sebab itu, hak asasi orang harus dihargai. Instansi pra peradilan memberi kepercayaan lebih untuk pengadilan negeri dalam memeriksa perkara berhubungan terhadap penggunaan upaya paksa (penggerebekan, penawanan, pemeriksaan, perampasan) dilakukan penyidik ,penuntut umum (Kuffal, 2011).

Pra peradilan sedemikian itu berarti dalam hukum acara pidana, desakan penerapan pra peradilan semakin mengeras dalam penduduk dituduh melancarkan tindak kejahatan. Akar beragam kejadian semisal kejadian budi gunawan tanggal

$16 / 2 / 2015$, pidana semasa ini terbentuk memamerkan maka pra peradilan memperlihatkan wujud pertahanan, tidak sekedar melibat keseimbangan, memperbedakan tentang keseimbangan HAM.

Keterkaitan pengatur negara membentuk negara indonesia selaku negara hukum berdasarkan pancasila dan UUD 1945, selaku kontekstual meyakini ajaran mengangkat HAM demi menyelamatkan kesetaraan penduduk negara di muka hukum demi mengangkat hukum dan pemerintahan tidak kecuali.

Kerapuhan berpokok KUHAP terlihat pendiri hukum ialah melalaikan hak si pelaku dalam mekanisme kejadian, dari tahap pemeriksaan, penagihan pada perundingan di muka hakim, kian bertambah mengenaskan lagi berlimpah sasaran dihinggap, disekap lewat tata cara yang sudah dimuat dalam perundangan.

Oleh sebab itu, terutama dalam penggunaan dan pelurusan hukum enggak lantaran negara atau pembesar sanggup menyelenggarakan dengan kebesaran satu patokan dapat berkhasiat, tapi patokan dirancang untuk keperluan dan menyelenggarakan kubu lesu jadi sentosa. Asal mula hakikatnya buatan patokan hukum teratur ialah betapa satu patokan perundangan mesti sanggup membahagi akan penduduk.

Kondisi terbilang orang memakai pra peradilan semacam usaha untuk memilih keseimbangan dalam mekanisme peradilan pidana. Asal faedah tidak lain ialah mengupayakan keselarasan antara keperluan hukum pribadi dan keperluan penduduk tanpa kecuali sebanding pembenaran ketetapan pasal 29 ayat (1) UUD 1945. Pra peradilan bagian mekanisme peradilan pidana, tidak bertujuan membantu, menjaga keselarasan dalam menetapkan orang jadi tersangka dilakukan adil.

Penetapan harus ada penunjang minimal dua barang bukti yang benar (Ashari, 2017). Bukti pendahuluan sebagai penegasan kepada terdakwa, aparat hukum memastikan tidak memihak. Penyimpangan warga mencari kebenaran memakai pra peradilan sebagai memperoleh keadilan dan perlindungan hak, utama menyangkut hak asasi. Pelaksanaan HAM dimuat dalam UUD 1945 dan dimuat dalam UU NO 8 Tahun 1981 berkaitan dengan KUHAP. UU memuat tentang mekanisme peradilan pidana dari tahap pemeriksaan, penagihan, persidangan.

Penelitian terdahulu yang terkait oleh (Atmoko Bobby, 2018) dan (Afandi, 2016) menyatakan bahwa praktik perluasan kewenangan praperadilan sebagai upaya kekuasaan yudisial yang menguji keabsahan upaya paksa yang dilakukan oleh penyidik. Namun, dengan kewenangan yang masih terbatas dan sifatnya yang pasif, praperadilan dipandang kurang efektif dalam mengawasi upaya paksa yang dilakukan aparat penegak hokum. Adapun tujuan penelitian ini yaitu mengetahui pengaturan praperadilan dalam sistem peradilan pidana di Indonesia dan mengetahui keabsahan dari praperadilan yang belum diputus apabila materi pokok perkara telah di sidangkan.

\section{METODE PENELITIAN}

Penelitian ini menggunakan metode hukum yang bersifat normative, melalui pendekatan perundangan, pendekatan secara faktual, pendekatan analisis konsep hukum. Pendekatan perundangan ialah pendekatan dengan menelaah semua peraturan perundangan dan regulasi bersangkut paut dengan isu hukum. yang dibentuk oleh lembaga negara atau pejabat yang berwenang 
dan mengikat secara umum. Pendekatan faktual membuat pendekatan didasarkan kenyataan benar terungkap dalam sejarah. Pendekatan konseptual yakni pendekatan dalam penelitian hukum menyampaikan sudut pandang analisa penuntasan masalah penelitian hukum dari aspek konsep hukum latar belakang, bahkan lihat dari nilai terkandung dalam norma. Sumber bahan hukum digunakan dalam penelitian ini yaitu bahan hukum primer dan bahan hukum sekunder. Sedangkan teknik pengumpulan bahan hukum dalam penelitian ialah dengan menggunakan studi dokumentasi dengan cara mengutip, dan memberi ulasan meringkas terkait dengan pokok masalah yang penulis buat yang mengenai upaya hukum praperadilan dalam sistem peradilan pidana di Indonesia.

\section{HASIL DAN PEMBAHASAN}

\section{Pengaturan PraPeradilan dalam Hukum Positif di Indonesia}

Pengaturan pra peradilan diatur dalam UU NO 8 Tahun 1981 perihal hukum acara pidana pada pasal 77 KUHP dimana pada pasal tersebut diatur terkait dengan Hukum Pidana formilnya yaitu bagaimana langkah pelaksanaan praperadilan. Praperadilan merupakan satu tindakan dilakukan pengadilan negeri memeriksa, memutus tentang kebenar penggerebekan, penawanan, pemberhentian pemeriksaan, pemberhentian penuntutan, memutus permintaan ganti kerugian dan rehabilitasi kejadian pidana tidak dilanjut ke sidang pengadilan negeri atas permohonan terdakwa, penasehat hukumnya (Mochamad Anwar HAK, Soeprijadi H, 1989). UU NO 8 Tahun 1981 KUHAP.

A. Benar atau tidak penggerebekan atau penawanan.

wewenang pertama diberikan UU pada Praperadilan. Memeriksa, memutus sah atau tidak:

a. Penggerebekan, Dalam menyidik suatu tindak pidana adakalanya penyidik harus mengadakan penangkapan atas tersangka pelakunya, merupakan suatu tindakan berupa pengekangan sementara waktu kebebasan terdakwa. Untuk melangsungkan penangkapan harus terpenuhi dua syarat, yaitu syarat formil, (1) Dilakukan polisi atas perintah penyidik. lengkap surat tugas yang berwenang. (2) Memberikan surat perintah penyidik pada tersangka dan tembusan pada keluarga. (3) Kecuali tertangkap tangan penangkapan dilakukan setiap orang. syarat material: (1) bukti permulaan cukup pasal 17 KUHAP, (2) Penangkapan paling lama satu hari 1x24 jam sesuai Pasal 19 ayat (1) KUHAP.

b. Penawanan yakni menempatkan si pelaku, tempat tertentu oleh pemeriksa, jaksa atau hakim. Tersangka mengajukan pemeriksa pra peradilan, bahwa tindakan penahanan dikenakan pejabat penyidik bertentangan dengan ketentuan pasal 21 KUHAP. penahanan dikenakan melewati batas waktu ditentukan pasal 24 KUHAP. Praperadilan penting diketahui ialah syarat-syarat dan tata cara mengadakan penahanan. Suatu penahanan yang tidak dilandasi Surat Perintah penahanan (SPP) dari penyidik atau penuntut umum atau penetapan hakim adalah tidak sah.

B. Benar atau tidak pemberhentian pemeriksaan atau pemberhentian penuntutan

Mengenai wewenangan pra peradilan yaitu mengusut, menahan benar atau tidak menghentikan pemeriksaan dilaksanakan pejabat pemeriksa tentang benar atau tidak menghentikan penagihan dilakukan jaksa, maka jaksa berwenang memberhentikan investigasi pemeriksaan, penagihan dengan hasil penyidikan, penagihan kurang bukti meneruskan perkara ke sidang pengadilan. Sebab, tidak bisa melanjutkan perkara sidang pengadilan. pemberhentian pemeriksaan, penagihan penyidik dan penunutut umum, disangka pada tersangka ialah tindak pidana pernah dituntut dan diadili, putusan memperoleh kekuatan hukum tetap. Penghentian dilakukan penyidik atau penuntut umum, disebabkan perkara disangkakan terhadap tersangka terdapat unsur kadaluarsa untuk penuntut. alasan penghentian tafsirkan secara tidak beralasan. Pemberhentian kepentingan individu pejabat tersebut. Oleh sebab itu, instansi wewenang mengusut, menilai benar atau tidak pemberhentian pemeriksaan, penagihan, agar tindakan tidak berlawanan pada hukum dan keperluan hukum mengawasi tindakan salah gunaan wewenang.

Pemberhentian penyidikan, UU memberikan hak jaksa, orang ketiga kepentingan mengusulkan penyidikan pada pra peradilan tentang benar atau tidak pemberhentian pemeriksaan. Sebaliknya pemeriksa, orang ketiga berkeinginan mengusulkan pemeriksaan benar atau tidak pemberhentian penuntutan pada praperadilan. 
C. Kerugian dan Rehabilitasi

Ganti rugi suatu hak orang mendapat pemenuhan atas tuntutan berupa upah uang. Timbulnya tuntutan ganti kerugian itu karena pemohon telah dikenai tindakan seperti apa yang diuraikan dalam Pasal 77 dan Pasal 95 KUHAP. Hal-hal yang diatur dalam Pasal 95 KUHAP sebagian sebelumnya sudah diatur dalam Pasal 77 KUHAP. Akan tetapi Pasal 95 KUHAP membuat dua pengertian pokok yang harus dipahami ialah tuntutan ganti kerugian bagi yang perkara pokoknya tidak pernah sampai ke pengadilan dan tuntutan ganti kerugian bagi perkara yang sudah diputus di Pengadilan.

\section{Keabsahan dari PraPeradilan yang Belum diputus Apabila Pokok Perkara telah di Sidangkan}

Putusan pra peradilan hakim tunggal sarpin rizaldi memperbolehkan pengajuan pra peradilan budi gunawan, memandang objek pengajuan pra peradilan diserahkan masuk objek pra peradilan. demikian, pengadilan negeri jakarta selatan bisa menilai benar atau tidak si pelaku kepada penagih. pertimbangan, hakim sarpin mengungkapkan, sprindik no 03/01/01/2015, 12/01/2015 budi gunawan tetap menjadi pelaku. Hakim menyatakan, kejadian pidana diperbuat budi gunawan bukan masuk subjek wewenang KPK sebagaimana ditegaskan wewenang KPK dimuat pada UU yakni pelaksana aparat hukum. Dari pertimbangan tersebut, hakim sarpin mengemukakan, sprindik 03/01/01/2015 landasan pemeriksaan pada Budi Gunawan tidak benar berdasar hukum.

Putusan praperadilan, hakim tidak memperbolehkan semua gugatan budi gunawan sebagai pemohon. Gugatan budi gunawan mendapatkan ganti kerugian oleh KPK tidak diterima hakim. Putusan Hakim menghapus biaya perkara diberikan negara. Pra peradilan berkaitan pada penyidikan diatur Pasal 77 KUHAP, yang mana hanya mengatur mengenai benar atau tidak pemberhentian pemeriksaan, karena itu materi pokok perkara praperadilan disidangkan dinyatakan gugur.

Dalam pasal 82 ayat (1) huruf d KUHAP mengenai gugur pra peradilan setelah pokok kejadian diselidiki, banyak dapat saran karena khawatir timbul praktek tidak sehat agar praperadilan gugur. dalam pasal 82 ayat (1) huruf d juga dianggap penting dalam menjaga tidak ada pertentangan mekanisme pemeriksaan maupun isi putusan perkara praperadilan dengan perkara pokok. Pengertian kapan perkara dianggap sudah diperiksa pengadilan negeri juga dapat perbedaan penilaian, sebagian berpendapat perkara sudah mulai diperiksa pengadilan negeri sejak perkara tersebut diberikan, ada berpendapat sejak perkara di sidangkan.

\section{SIMPULAN DAN SARAN}

\section{Simpulan}

Pengaturan praperadilan dalam sistem peradilan pidana dalam hal ini diatur di dalam UU NO 8 Tahun 1981 tentang hukum acara pidana pasal 77 KUHAP yaitu praperadilan ialah wewenang pengadilan negeri memeriksa dan memutus terkait sah atau tidak atau penahanan, sah atau tidak pemberhentian penyidikan atau pemberhentian penuntutan, permintaan ganti kerugian ,rehabilitasi. Tambahan MK No 21/PUU-XII/2014, wewenang lembaga praperadilan juga termasuk sah atau tidak penetapan tersangka, penggeledahan dan penyitaan. Keabsahan praperadilan yang belum diputus materi apabila materi pokok perkara telah disidangkan pada mekanisme penyidikan dilakukan KPK terkait penetapan tersangka Budi Gunawan tidak sah dan karena penetapan tidak memiliki kekuatan hukum mengikat. Oleh karena itu materi pokok perkara praperadilan yang disidangkan dinyatakan gugur.

\section{Saran}

1. Bagi pemerintah turut memantau dan memperjuangkan hak-hak tersangka sehingga terjadinya kesetaraan Hukum dan terwujudnya asas equality before the law.

2. Bagi penegak Hukum di harapkan selalu menegakkan Hukum berdasarkan Hukum materiil dan formil yang ada dan berlaku di masyarakat.

3. Bagi masyarakat pra peradilan dapat bermanfaat untuk menuntut keadilan bilamana penegak Hukum dalam hal ini penyidik tidak melaksanakan tugasnya berdasarkan SOP.

\section{DAFTAR PUSTAKA}

Afandi, F. (2016). Perbandingan Praktik Praperadilan dan Pembentukan Hakim Pemeriksa Pendahuluan dalam Peradilan Pidana Indonesia. Mimbar Hukum - Fakultas Hukum Universitas 
Gadjah Mada, 28(1), 93.

Alfifah, R. N. (1986). Peradilan dan Ruang Lingkupnya. Akademika Pressindo.

Ashari, A. (2017). Peranan Barang Bukti dalam Proses Perkara Pidana. 1(3), 1-18.

Atmasasmita, R. (1983). Hukum Acara Pidana. Bunga Rampai , Binacipta.

Atmoko Bobby, A. D. (2018). Kedudukan Hukum Penyidik terhadap Obyek Praperadilan. 2(1), 1-17. Kansil, C. S. . (1989). Pengantar Ilmu Hukum dan Tata Hukum Indonesia. Balai Pustaka.

Kuffal, H. (2011). Penerapan KUHP dalam Praktik Hukum. UMM Press.

Mochamad Anwar HAK, Soeprijadi H, C. S. (1989). Praktek Peradilan Pidana di Indonesia. IndHill-Co. 